\title{
Molt related mortalities of the Dungeness crab Cancer magister caused by a marine facultative ciliate Mesanophrys pugettensis
}

\author{
J. Frank Morado ${ }^{1, *}$, Ray H. Giesecke ${ }^{2}$, Stephen E. Syrjala ${ }^{1}$ \\ ${ }^{1}$ National Oceanic \& Atmospheric Administration, National Marine Fisheries Service, Alaska Fisheries Science Center, \\ Resource Assessment \& Conservation Engineering Division, 7600 Sand Point Way NE, Seattle, Washington 98115-0070, USA \\ ${ }^{2} 353$ Cove Road, Bellingham, Washington 98226, USA
}

\begin{abstract}
In May of 1990, a number of Dungeness crabs Cancer magister were found dead or dying on a private beach in Samish Bay, Washington, USA. The hemolymph of a small number of randomly collected crabs was examined by bright field microscopy and found to be infected by a recently described ciliate Mesanophrys pugettensis. The same ciliate was found in subsequent 1990 collections of Dungeness, rock $C$. productus and kelp Pugettia producta crabs collected at the private beach and Clayton Beach, Samish Bay, Washington. M. pugettensis was again encountered in Dungeness and rock crabs collected from the same survey sites in 1991 and 1992, but not in limited beach collections in 1993. During the 1990-1992 survey period, a total of 654 Dungeness crabs were collected from the 2 study sites. Logistic regression analysis indicated that shell condition and size (i.e. carapace width) are significant predictors of ciliate infection $(p<0.0001, p<0.005$, respectively); the probability of infection is highly correlated with increase in carapace width. This is the first report implicating a ciliate as a cause of remarkable, wild crab mortalities and the first to clearly associate non-apostome ciliate infections with molting. The similarities of Dungeness crab ciliate disease to other protistan diseases of wild crustaceans is discussed, suggesting that a number of other protistan pathogens likely enter their host during or shortly after molting
\end{abstract}

KEY WORDS: Dungeness crab Cancer magister Crustacean. Molt Mesanophrys pugettensis . Ciliate Mortalities

\section{INTRODUCTION}

The recorded history of histophagous, philasterine scuticociliate infections of crustaceans is sporadic and their taxonomic status has been a major point of confusion (Armstrong et al. 1981, Morado \& Small 1994, 1995). The genus Anophrys was established when a free-living marine ciliate was found feeding on dead animal tissue in an aquarium (Cohn 1866). Philasterine scuticociliate infections were subsequently encountered in wild and captive crustaceans (Morado \& Small 1994, 1995), but the first adequate description did not occur until 1977 (Groliere \& Leglise 1977). However, in

•E-mail: frank.morado@noaa.gov the last few years, 3 new philasterine scuticociliates, Mesanophrys pugettensis (Morado \& Small 1994), M. chesapeakensis (Messick \& Small 1996) and Anophryoides haemophila (Cawthorn et al. 1996), that infect crustaceans and cause mortalities have been described. In addition, a ciliate identified as Tetrahymena pyriformis was recently found infecting and causing mortalities in the Australian crayfish Cherax quadricarinatus (Edgerton et al. 1996).

Since 1985, Dungeness crab mortalities have been reported throughout Northern Puget Sound, Washington, but their causes were not identified. In May 1987, a mass mortality of Dungeness crabs at Larabee State Park in Samish Bay, Washington, was reported. Five moribund crabs were examined of which $2(40 \%)$ were found infected with Mesanophrys pugettensis, as later 
described by Morado \& Small (1994). Two weeks later, 10 additional crabs were collected and examined of which $3(30 \%)$ were infected by $M$. pugettensis. In late June 1987, the blood of 100 crabs captured by a ring net at $10 \mathrm{~m}$ depth at the state park was examined, but none were $M$. pugettensis positive. Dungeness crab mortalities were again reported at the same location in the spring of 1988, but not investigated. In May 1990, large numbers of crabs were observed dying at a private beach in Samish Bay, less than $150 \mathrm{~m}$ north of the 1987 mortality site (R.H.G. pers obs.). In total, 1 moribund and 5 dead Dungeness crabs were brought to the laboratory for examination, but because the cause of death could not be determined with certainty, a field sampling scheme was initiated at the private beach and at Clayton Beach, a public beach located $2.5 \mathrm{~km}$ south of Larabee State Park. M. pugettensis was found in the 1990 crab collections and again at both study sites in 1991 and 1992. Because experimental studies show that $M$. pugettensis infections are fatal (Armetta $\&$ Morado in press), the results from these and previous crab collections are reported with respect to the prevalence and distribution of systemic ciliate disease in populations of several North Pacific crab species.

\section{METHODS}

Sexually mature Dungeness crabs were collected by crab pot, ring net, otter trawl and by SCUBA diver from Washington, but primarily Puget Sound (Fig. 1), Oregon, California and Alaska from 1978 to 1992. During the summers from 1990 to 1992 , sexually mature male and female Dungeness crabs and 3 other crab species (Cancer productus, Pugettia producta, Telmessus chironomus) were collected from a private beach and Clayton Beach in Samish Bay at low tide from exposed inter-tidal areas and by dip net at depths ranging to 5 feet $(1.524 \mathrm{~m})$. Data recorded from all crab species included collection date, location, species, sex, carapace width $(\mathrm{mm})$ and shell condition with respect to molting status and wear $(0$, well developed new exoskeleton under old exoskeleton; 1 , molted, exoskeleton soft to paper shell condition; 2, carapace firm to hard, lacking scratches, wear, discoloration and epibionts/ epiphytes; 3, encrusting organisms may be present, some wear evident, darker in color; 4, abundant scratches, wear and stains, encrusting organisms common and usually abundant).

To determine the presence or absence of Mesanophrys pugettensis in the hemolymph of collected crabs, the distal portion of a periopod dactylus was snipped with a pair of scissors. Several drops of blood were allowed to escape before 1 drop was placed on a slide and inspected by bright field microscopy $(25 \times$

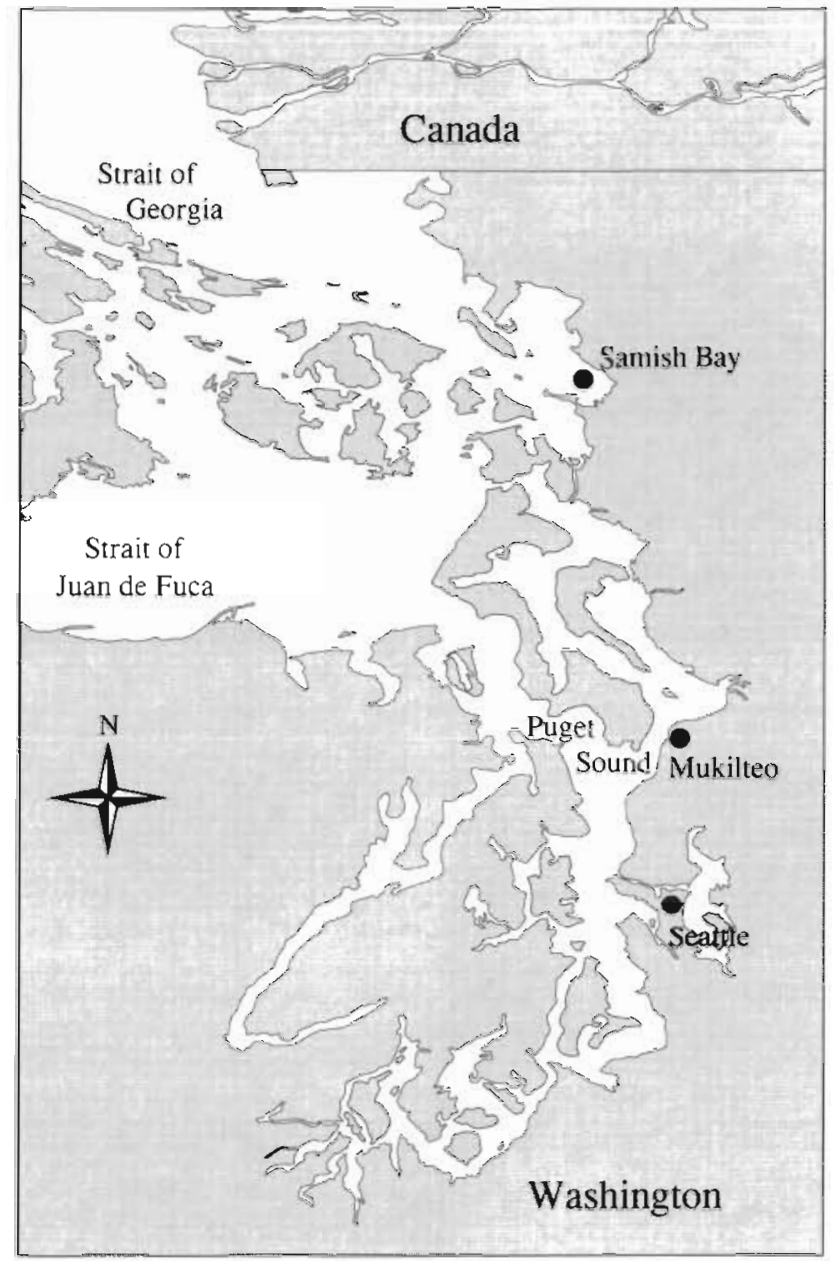

Fig. 1. The Puget Sound region, Washington, showing locations of major Dungeness crab collection sites

magnification). At least $5 \mathrm{ml}$ of blood was withdrawn from several infected crabs and refrigerated for subsequent in vitro culture and identification of the ciliated parasite.

For ciliate identification, thin blood smears were prepared on acid alcohol cleaned slides that were coated with $10 \%$ poly-L-lysine. Blood smears, while still wet were then quickly placed upside-down in freshly made and filtered Bouin's solution (Lee et al. 1985) for 30 min. The modified protargol staining method of Tuffrau (1967) was applied to the fixed blood smears.

A backward step-wise logistic regression (Hosmer \& Lemeshow 1989, Fisher \& van Belle 1993) was used to analyze the data to determine which variables (i.e. collection year, collection site, sex, size, shell condition), if any, were significant predictors of ciliate infection. A simple regression was fitted to the prevalence data (e.g. number infected/sample size for each collection) in an effort to compare infection trends between males and females during the survey. 


\section{RESULTS}

\section{Ciliate identification}

When the blood of infected crabs was examined by bright field microscopy, it was clear that the ciliates from infected crabs were morphologically similar (i.e. fusiform in shape, similar length and width, single caudal cilium). Protargol staining of blood smears prepared from randomly selected crabs confirmed their morphological similarity to Mesanophrys pugettensis (Morado \& Small 1994).

\section{Non-Samish Bay Dungeness crab collections}

From 1978 to 1992, a total of 813 Dungeness crabs were collected from Washington ( $n=779$ ), Oregon $(\mathrm{n}=24)$ and northern California $(\mathrm{n}=10)$. An additional 78 were collected from Southeast Alaska. The largest Dungeness crab collection was made near Mukilteo, Washington ( $\mathrm{n}=623$, Fig. 1 )

Between 1978 and 1992, 4 of 779 (0.5\%) Dungeness crabs from throughout Washington State were found infected with Mesanophrys pugettensis. All 4 possessed a remarkable hemocytopenia even though only 1 crab was considered lightly infected. Ciliate infec- tions were not detected in Dungeness crabs collected from Oregon, Northern California and Alaska.

\section{Alaska non-Dungeness crab collections}

During the 1978-1992 sampling period, 239 Tanner crabs Chionoecetes bairdi were collected from the Gulf of Alaska. Several crab species from the Bering Sea were also collected, including Alaskan red Paralithodes camtschaticus $(\mathrm{n}=1289$ ), blue $P$. platypus $(\mathrm{n}=606$ ) and golden Lithodes aequispina $(\mathrm{n}=168)$ king crabs, Tanner Chionoecetes bairdi $(\mathrm{n}=410)$ and snow C. opilio ( $\mathrm{n}=$ 1442) crabs, and hair crab Erimacrus isenbeckii $(n=45)$. None of these crabs were found with a ciliate infection.

\section{Samish Bay collections}

Between 1987 and 1992, Dungeness crabs were collected from several sites in Samish Bay, Washington ( $n=1160$, Fig. 1); the majority came from Clayton Beach and a nearby private beach. During the beach sampling period, male crabs were more prevalent than females at the private beach (approximately 5:1), while the male to female ratio at Cldyton Beach was approximately 1:1 (Table 1). A total of 654 Dungeness crabs

Table 1 1990-1992 prevalences of the facultative parasitic ciliate in collected Dungeness crabs from the private and Clayton Beaches, Samish Bav, WA

\begin{tabular}{|c|c|c|c|c|c|c|c|c|c|}
\hline $\begin{array}{l}\text { Cumulative } \\
\text { shell condition }\end{array}$ & No. & $\begin{array}{c}\text { Total } \\
\text { No. infected }\end{array}$ & $\%$ infected & No. & $\begin{array}{c}\text { Males } \\
\text { No. infected }\end{array}$ & $\%$ infected & No. & $\begin{array}{c}\text { Females } \\
\text { No. infected }\end{array}$ & $\%$ infected \\
\hline 0 & 98 & 2 & 2.0 & 19 & 0 & 0.0 & 79 & 2 & 2.5 \\
\hline 1 & 164 & 64 & 39.0 & 137 & 59 & 43.1 & 27 & 5 & 18.5 \\
\hline 2 & 104 & 11 & 10.6 & 88 & 9 & 10.2 & 16 & 2 & 12.5 \\
\hline 3 & 276 & 19 & 6.9 & 152 & 14 & 9.2 & 124 & 5 & 4.0 \\
\hline 4 & 12 & 2 & 16.7 & 5 & 1 & 20.0 & 7 & 1 & 14.3 \\
\hline Totals & 654 & 98 & 15.0 & 401 & 83 & 20.7 & 253 & 15 & 5.9 \\
\hline \multicolumn{10}{|l|}{$\begin{array}{l}\text { Private beach } \\
\text { shell condition }\end{array}$} \\
\hline 0 & 25 & 0 & 0.0 & 17 & 0 & 0.0 & 8 & 0 & 0.0 \\
\hline 1 & 147 & 62 & 42.2 & 132 & 58 & 43.9 & 15 & 4 & 26.7 \\
\hline 2 & 30 & 2 & 6.7 & 29 & 2 & 6.9 & 1 & 0 & 0.0 \\
\hline 3 & 22 & 1 & 4.5 & 6 & 0 & 0.0 & 16 & 1 & 6.2 \\
\hline 4 & 0 & 0 & 0.0 & 0 & 0 & 0.0 & 0 & 0 & 0.0 \\
\hline Totals & 224 & 65 & 29.0 & 184 & 60 & 32.6 & 40 & 5 & 12.5 \\
\hline \multicolumn{10}{|l|}{$\begin{array}{l}\text { Clayton Beach } \\
\text { shell condition }\end{array}$} \\
\hline 0 & 73 & 2 & 2.7 & 2 & 0 & 0.0 & 71 & 2 & 2.8 \\
\hline 1 & 17 & 2 & 11.8 & 5 & 1 & 20.0 & 12 & 1 & 8.3 \\
\hline 2 & 74 & 9 & 12.2 & 59 & 7 & 11.9 & 15 & 2 & 13.3 \\
\hline 3 & 254 & 18 & 7.1 & 146 & 14 & 9.6 & 108 & 4 & 3.7 \\
\hline 4 & 12 & 2 & 16.7 & 5 & 1 & 20.0 & 7 & 1 & 14.3 \\
\hline Totals & 430 & 33 & 7.7 & 217 & 23 & 10.6 & 213 & 10 & 4.7 \\
\hline
\end{tabular}


was collected at Clayton Beach $(n=430)$ and the private beach ( $\mathrm{n}=224$; Table 1) between 1990 and 1992 when the spring/summer mortalities were observed, of which 98 were infected by Mesanophrys pugettensis.

Deep water (>30 m) Dungeness crab collections were made in 1988 from Samish Bay ( $n=300$, Fig. 1) and from other embayments in Samish Bay in conjunction with the 1991 Puget Sound Ambient Monitoring Program (PSAMP) $(n=206)$. Ciliate infections were not detected in either of these deep-water Dungeness crab collections.

During the 1990-1992 beach survey, 101 red rock Cancer productus, 7 northern kelp Pugettia producta, and 6 helmet Telmessus chironomus crabs were also collected and examined for the presence of the ciliate. From these sample sets, 3 of 87 Shell Condition- 1 red rock crabs $\left(3.4 \% ; 2 \sigma^{\prime}\right.$ and $\left.1 \%\right)$ were found infected, while no ciliate infections were detected in collected helmet crabs. A total of 2 of 7 (28.6\%) Shell Condition1 northern kelp crabs, both of which were males, were found with ciliate infections.

During the beach survey, $15 \%$ of all Dungeness crabs (Table 1; $\mathrm{n}=654$ ) collected from the 2 principal sites were found infected with the ciliated protist. Hemolymph of moderately infected crabs was typically clear as most of the blood cells had been removed from circulation by the ciliate. Only a few of the infected crabs possessed extreme ciliate densities and milky hemolymph.

The results of logistic regression analysis on the Dungeness crab beach data show that shell condition and carapace width are statistically significant predictors of ciliate infection (Table 2a). Logistic regression

Table 2a. Backward step-wise logistic regression of crab collection variables as predictors of ciliate infection.

\begin{tabular}{|lc|}
\hline Significant model effects & Level of significance \\
Shell condition & $<0.0001$ \\
Size & 0.003 \\
Non-significant effects & \\
Year & 0.60 \\
Collection location & 0.40 \\
Sex & 0.13 \\
Shell condition $\times$ size interaction & 0.74 \\
&
\end{tabular}

Table 2 b. Levels of significance for significant variables shell condition and size

\begin{tabular}{clc}
\hline Significant model parameter values & \\
Intercepts: & Shell Condition-0 & -6.41 \\
& Shell Condition-1 & -3.31 \\
& Shell Condition-2 & -4.93 \\
& Shell Condition-3 & -5.40 \\
& Shell Condition-4 & -4.53 \\
Slope: & Size & 0.0187
\end{tabular}

further demonstrated that the remaining variables (i.e collection location, year of collection, sex) and the interaction variable between shell condition and carapace are not significant predictors of infection (Table 2a). The resultant model to predict the probability of ciliate infection is:

$$
P(\text { Ciliate Infection })=\frac{\exp \left(\alpha_{i}+\beta \mid \omega\right)}{1+\exp \left(\alpha_{1}+\beta \mid \omega\right)}
$$

where $i=0,1,2,3,4$ and denotes shell condition, $\alpha_{i}$ denotes the effects of $i^{\text {th }}$ shell condition, and $\beta$ denotes the effect of carapace width $(\omega)$. Parameter estimates for $\alpha_{i}$ and $\beta$ are given in Table $2 b$, and a graph showing the estimated probability of infection is presented in Fig. 2. The predictive model indicates that crabs of Shell Condition-1 are most likely to be infected, followed in order by crabs with Shell Conditions $-4,-2$ and -3. Crabs of Shell Condition-0 are least likely to be infected. The model further indicates that an increase in carapace width correlates with an increase in infection probability.

Even though infection prevalences between sexes and collection sites were not statistically significant, they were nevertheless remarkable and are discussed briefly. Infections were more prevalent at the private beach $(29 \%$; Table 1) than at Clayton Beach (7.7\%). Overall infection prevalences were highest in Shell Condition- 1 males and females $(43.1 \%$ and $18.5 \%$, respectively; Table 1). At the private beach, infections were most common in Shell Condition-1 male and female crabs $(43.9$ and $26.7 \%$ respectively; Table 1 , Fig. 3). Infections in Shell Condition-1 crabs from Clayton Beach were not as remarkable because fewer Shell Condition-1 crabs were collected and detected with ciliate infections (Table 1, Fig. 4). In general, infections in Shell Condition-1 crabs at Clayton Beach were much reduced and approximated infection prevalences for the other shell condition classes (Table 1 ,

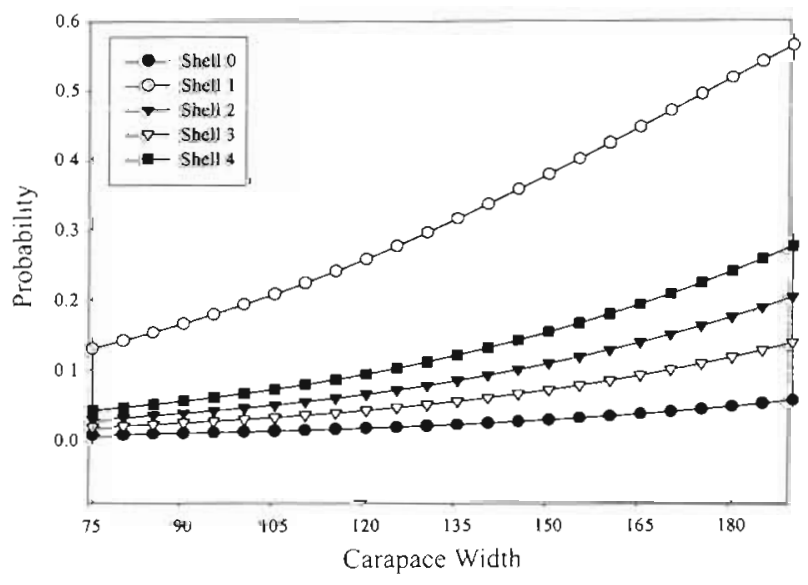

Fig. 2. Probability of ciliate infection with carapace width 


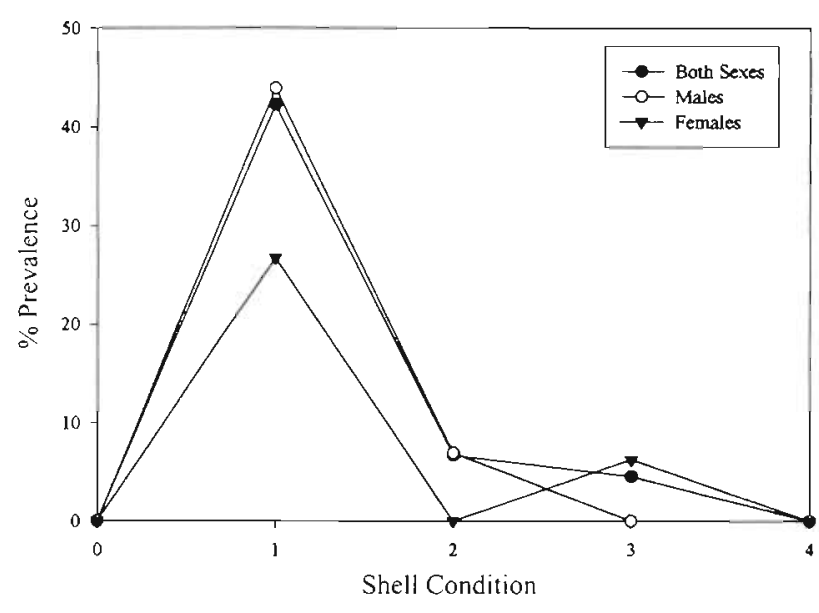

Fig. 3. Sex and shell condition of ciliate infected Dungeness crabs from the private beach, 1990-1992

Fig. 5). The combined sex data for each collection site thus indicate that prevalences are highest in Shell Condition-1 crabs at the private beach $(42.2 \%)$. No clear trend was observed in crabs collected from Clayton Beach, but infection prevalences appear slightly elevated for crabs of Shell Conditions- 2 to -4 when compared to the same groups at the private beach (Table 1, Fig. 5)

\section{Samish Bay infection trends}

Because crab collections at the 2 principal collection sites were made over several months (e.g. May to July, 1990 to 1992), general infection trends were tracked (Fig. 6). The data from both collection sites were combined and plotted to better reveal and contrast infection trends in male and female crabs. Treatment of the date-specific prevalence data in this manner indicates

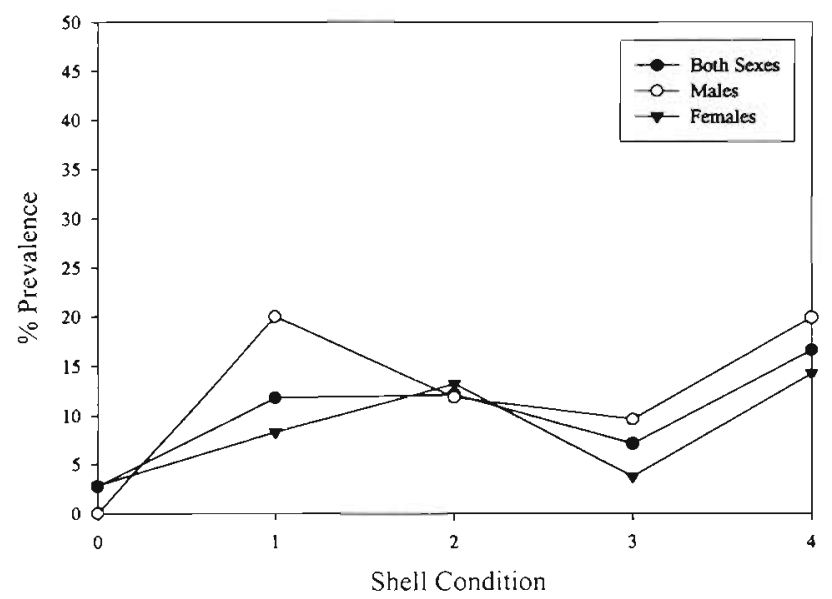

Fig. 4. Sex and shell condition of ciliate infected Dungeness crabs from Clayton Beach, 1990-1992

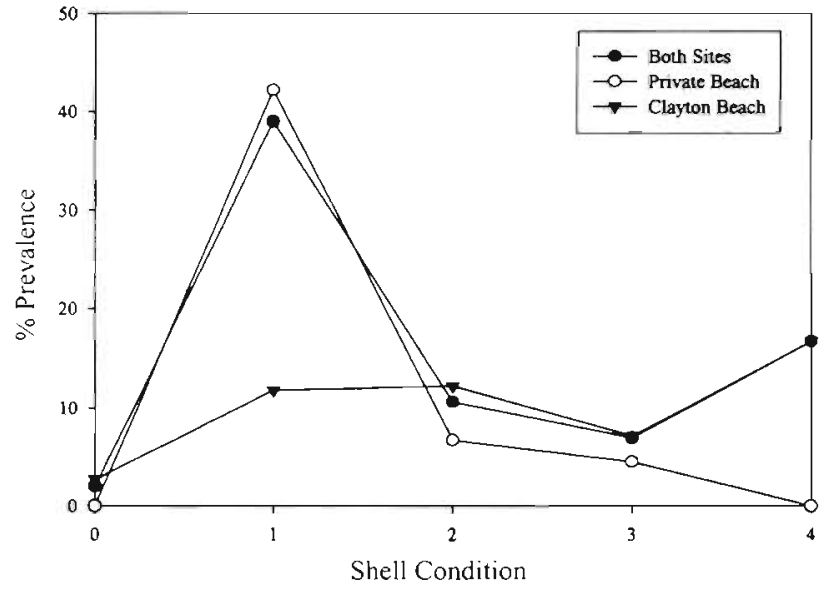

Fig. 5. Sex and shell condition of ciliate infected Dungeness crab from both collection sites, 1990-1992

that infections are more prevalent in males than females in the spring. However, as the summer progressed, infection prevalences steadily dropped in males while they increased slightly in females.

\section{DISCUSSION}

\section{Disease and wild crustacean populations}

The role of disease in wild fish and shellfish population fluctuations has only recently received broad attention despite historical data demonstrating its importance in humans and terrestrial animals. While it is clear that some disease-causing agents have lethal propensities, progress in understanding the role of disease on wild fish and shellfish populations has been impeded because both host and pathogen remain hidden from view. Complete life histories of pathogens are typically unknown as is the possible role of reservoirs or alternate hosts. In addition, the nature of crustacean recruitment processes is not fully understood (Kuris \& Lafferty 1992). Furthermore, a natural biological process may obscure the impact of disease on wild crustacean populations. For example, the intense molting activity of male Dungeness crabs that occurred in the spring of each sampling year disguised the presence of a causative agent; it was originally thought that the observed mortalities were routine molting mortalities. Only after several lethargic individuals were examined more carefully was the ciliate discovered in recently moribund as well as normal, active crabs.

Few crustacean diseases are well understood even though they may be considered important factors in host population fluctuations (Sparks 1985, Sindermann 1990). For example, consider the differences between grey crab disease (GCD) of the eastern blue crab Call- 


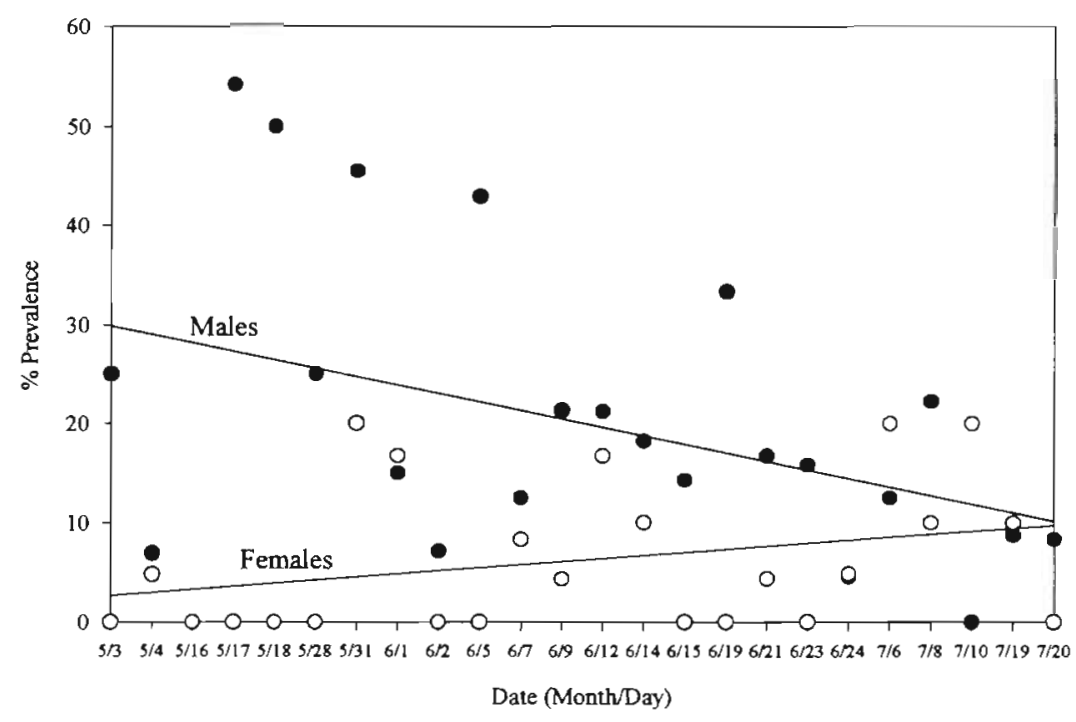

Fig. 6. Infection trends for male and female Dungeness crabs collected during the 1990-1992 survey period. (-) \% infection in male crabs, (0) \% infection in female crabs

inectes sapidus, bitter crab syndrome (BCS) of Alaskan Tanner crabs Chionoecetes bairdi and C. opilio to Dungeness crab ciliate disease (DCCD). Both GCD and BCS are caused by parasitic protists Paramoeba perniciosa (Sprague et al. 1969) and Hematodinium sp. (Meyers et al. 1987), respectively, that are fatal and produce significant mortalities. In some areas of Southeast Alaska, BCS may approach 100\% prevalence (Meyers et al. 1987), but its impact on C. bairdi populations may not be immediately felt, as BCS appears to be a chronic disease possessing a 12 to 18 mo cycle (Meyers et al. 1987, 1990, Eaton et al. 1991). On the other hand, GCD is a relatively acute disease, producing experimental mortalities via transfer of un-quantified inocula in 34 to 39 d (Johnson 1977). In the wild, prevalences may approach $35 \%$ in 'peeler' crabs, but only $8 \%$ in hard shell crabs (Sawyer 1969). The pathogenesis of DCCD appears similar to GCD in both its acute nature and the apparent selective nature for infection in imminently ready or recently molted crabs. For all 3 diseases, the mechanism for, and the portal of, parasite entry are unknown. The presumptive evidence suggests that the causative agents of GCD, BCS and DCCD are likely to gain entry into their respective hosts through wounds.

\section{Disease and molting}

Crustaceans must molt to grow even though it is not a universal and necessary event for mating (Paul et al. 1983, Paul 1984, Conan \& Comeau 1986). Recently molted crustaceans are extremely vulnerable to injuries that may result in overt or concealed perforations in the new exoskeleton. This likely explains the increase in the probability for ciliate infection in Shell Condition-1 Dungeness crabs.

A similar relation between molting and parasitism is likely to exist for BCS and GCD. Meyers et al. (1990) and Eaton et al. (1991) proposed such a correlation between molting and infection prevalences, and similar but untested correlations were also observed with GCD by Johnson (1977), Sawyer (1969) and Sprague \& Beckett (1966). Perforations of the exoskeleton need not be large, as Hematodinium, Paramoeba perniciosa and Mesanophrys pugettensis are all small parasites ranging in average size from 5 to $53 \mu \mathrm{m}$

The seasonal behavior of the Dungeness crab, an active and aggressive crustacean, is likely to exacerbate the potential for injury and subsequent pathogen entry. Both sexes migrate vertically from deep to shallow water to molt and subsequently mate. In the inland waters of Washington State, males generally molt prior to females (Dinnel et al. 1986, 1987). Male molting activity in Samish Bay, Washington, generally peaks during a 30 to $45 \mathrm{~d}$ period that begins at or about midMay (authors' pers. obs.). In contrast, the molting period of females is more protracted and generally occurs from late April to August. Thus, Dungeness crab molting behavior coupled with their aggressive behavior toward other crabs and the existence of the ciliate in the water column likely explains the observed summer infection trends in male and female crabs (Fig. 6).

It appears unlikely that infections were obtained by feeding because fewer hard shell crabs were found infected with the ciliate relative to newly molted crabs. In addition, Shell Condition-0 ('peeler') crabs tend not to feed prior to and shortly after molting. Indeed, O'Halloran \& O'Dor (1988) reported that male snow crabs stopped feeding 3 to $6 \mathrm{wk}$ prior to molting and did not resume feeding until 3 to 4 wk after molting. Experimental laboratory results (Morado unpubl. data) indicate experimentally wounded crabs are more likely to become infected by ciliates than via the ingestion route, and that experimentally injected crabs $\left(10^{6}\right.$ ciliates $\mathrm{kg}^{-1}$ wet weight of crab) die in approximately 10 to $12 \mathrm{~d}$. Thus, wild crabs that become infected by small numbers of ciliates during the molting period are not likely to survive beyond 3 to $4 \mathrm{wk}$.

Undamaged, the exoskeleton is a formidable barrier to many potential pathogens. Even uncalcified chitin, such as that which can be found around arthrodial 
joints and the gills, likely poses an effective barrier to non-apostome ciliates. Corliss (1960) proposed that the cuticle of midge larvae was of sufficient thickness $(\geq 7 \mu \mathrm{m})$ to prevent infections of Tetrahymena chironomi. In contrast, a tetrahymenine ciliate is apparently able to penetrate the cuticle of mosquito larvae that is approximately $14 \mu \mathrm{m}$ thick (Clark \& Brandl 1976); however penetration into the mosquito larva appears to occur following encystment of the ciliate on its host. At the present time, there is no evidence to suggest that Mesanophrys pugettensis either encysts or is able to directly penetrate the Dungeness crab exoskeleton.

\section{Ciliate diseases of crustaceans}

Histophagous, philasterine scuticociliates are widely distributed in nature and have a long and sporadically recorded history in marine crustaceans. Excluding the Clayton Beach/private beach data, cumulative data from Cattaneo (1888), Poisson (1930), Sparks et al. (1982) and Hibbits \& Sparks (1983) indicate that ciliate infections of crustaceans are rare (13 of 9150 or $0.14 \%$ ). Inclusion of the American lobster data (Sherburne \& Bean 1991) raises the infection prevalence in wild crustaceans to $1.1 \%$ (103 of 9240). As a result, little evidence has been gathered to indicate that histophagous ciliates would or should be considered important disease-causing agents of crustaceans. Furthermore, no evidence has been presented to suggest that ciliate infections were associated with a natural biological phenomenon eventhough Aiken \& Waddy (1986) presented data that indicated increased ciliate infections in the American lobster were associated with cold water temperatures.

These historical observations are in marked contrast to the present results where overall infection prevalences were 15\% during the 1990-1992 sampling period. The majority of infections occurred in recently molted crabs and were more common in males than in females. Interestingly, Cattaneo (1888) noted that the single infected crab of 300 examined was a male and had recently molted. The present data also suggest that ciliate infections were more prevalent in crabs collected at shallow depths where molting is more likely to occur. Since 1978, only 2 of 1346 Dungeness crabs collected by otter trawl, crab pot, ring net and SCUBA were found infected with the ciliate. In contrast, 98 of $654(15 \%)$ crabs collected by dip net at low tide from the private beach and Clayton Beach were infected with Mesanophrys pugettensis, with the majority of those infections coming from Shell Condition-1 crabs (64 of 164 or $39 \%$ ). None of the Dungeness crabs caught by otter trawl in conjunction with the 1991 PSAMP survey $(n=206)$ were positive for the ciliate even though these collections were made from May 16 to 22,1991 , and in the general vicinity of the 1990 to 1992 sampling sites. Ciliate infections were also absent in 100 Dungeness crabs (Shell Condition-2) captured by ring net at $10 \mathrm{~m}$ depth in 1987 shortly after a reported mortality.

The marked difference in ciliate prevalence between the private beach and Clayton Beach can be attributed to differences in shell condition and size between the 2 sampling sites. Crab collections made in late spring of each sampled year were dominated by large males of Shell Condition-1. However, it is likely that sporting activities at Clayton Beach affected collections as the Dungeness crab fishery is a male directed fishery. During the survey period many paired (copulating) crabs were encountered; thus it is possible that lightly infected male crabs were removed by sport crabbers and that in separating mating pairs, females and undersized males may have been injured.

This report suggests that ciliate-induced mortalities of crustaceans may be more frequent and important than once believed as no other pathogen was encountered during the 3 yr sampling period. Even though the impact of ciliate epizootics on crustacean populations is uncertain, this study does emphasize the need to more carefully investigate mortalities associated with a natural, biological phenomena such as molting.

\section{LITERATURE CITED}

Aiken DE, Waddy SL (1986) Environmental influence on recruitment of the American lobster. Homarus americanus: a perspective. Can J Fish Aquat Sci 43:2258-2270

Armstrong DA, Burreson EM, Sparks AK (1981) A ciliate infection (Paranophrys sp.) in laboratory-held Dungeness crabs, Cancer magister. J Invertebr Pathol 37:201-209

Cattaneo G (1888) Su di un infusorio ciliato, parasito del sangue del Carcinus maenus. Zool Anz 11:456-459

Cawthorn RJ, Lynn DH, Despres B, MacMillan R, Maloney R, Loughlin M, Bayer R (1996) Description of Anophryoides haemophila n. sp., (Scuticociliatida: Orchitophryidae), a pathogen of American lobsters Homarus americanus. Dis Aquat Org 24:143-148

Clark TB, Brandl DG (1976) Observations on the infection of Aedes sierrensis by tetrahymenine ciliate. J Invertebr Pathol 28:341-349

Cohn F (1866) Neue Infusorien im Seeaquarium. Z Wiss Zool $16: 253-302$

Conan GY, Comeau M (1986) Functional maturity and terminal molt of male snow crab, Chionoecetes opilio. Can J Fish Aquat Sci 43:1710-1719

Corliss JO (1960) Tetrahymena chironomi sp. nov., a ciliate from the midge larvae, and the current status of facultative parasitism in the genus Tetrahymena. Parasitology 50 : 111-153

Dinnel PA, Armstrong DA, McMillan RO (1986) Dungeness crab, Cancer magister, distribution, recruitment, growth, and habitat use in Lummi Bay, Washington. Univ. Washington, Fish Res Inst Final Rep FRI-UW-8612 
Dinnel PA, McMillan RO, Armstrong DA, Wainwright TC, Whiley AJ, Burge R, Baumgarner R (1987) Padilla Bay Dungeness crab. Cancer magister, habitat study. Univ. Washington, Fish Res Inst Final Rep FRI-UW-8704

Eaton WD, Love DC, Botelho C, Meyers TR, Imamura $K_{\text {, }}$ Koeneman T (1991) Preliminary results on the seasonality and life cycle of the parasitic dinoflagellate causing bitter crab disease in Alaskan Tanner crabs (Chionoecetes bairdi). J Invertebr Pathol 57:426-434

Edgerton B, O'Donaghue P, Wingfield M. Owen L (1996) Systematic infection of freshwater crayfish Cherax quadricarinatus by hymenostome ciliates of the Tetrahymena pyriformis complex. Dis Aquat Org 27:123-129

Fisher LD, van Belle G (1993) Biostatistics: a model for the health sciences. John Wiley \& Sons, Inc, New York

Groliere CA, Leglise M (1977) Paranophrys carcini n. sp., cilie Philasterina récolté dans l'hémolymphe du crabe Cancer pagurus Linne. Protistologica 13:503-507

Hibbits J, Sparks AK (1983) Observations on the histopathology caused by a parasitic ciliate (Paranophrys sp.?) in the isopod Gnorimosphaeroma oregonensis. J Invertebr Pathol 41:51-56

Hosmer DW, Lemeshow S (1989) Applied logistic regression. John Wiley \& Sons, New York

Johnson PT (1977) Paramoebiasis in the blue crab, Callinectes sapidus. J Invertebr Pathol 29:308-320

Kuris AM, Lafferty KD (1992) Modelling crustacean fisheries: effects of parasites on management strategies. Can J Fish Aquat Sci 49:327-336

Lee JJ, Small EB, Lynn DH, Bovee EC (1985) Some techniques for cultivating and observing protozoa. In: Lee JJ, Hutner $\mathrm{SH}$, Bovee EC (eds) An illustrated guide to the Protozoa. Society of Protozoologists, Lawrence, KA, p 1-7

Messick GA, Small EB (1996) Mesanophrys chesapeakensis n. sp.. parasite morphology and observed histology in the blue crab Callinectes sapidus. Invertebr Biol 115:1-12

Meyers TR, Koeneman TM, Botelho C, Short S (1987) Bitter crab disease: a fatal dinoflagellate infection and marketing problem for Alaskan Tanner crabs Chionoecetes bairdi. Dis Aquat Org 3:195-216

Meyers TR, Botelho C, Koeneman TM, Short S, Imamura K (1.990) Distribution of bitter crab dinoflagellate syndrome in southeast Alaskan Tanner crabs Chionoecetes bairdi. Dis Aquat Org 9:37-43

Morado JF, Small EB (1994) Morphology and morphogenesis Mesanophrys pugettensis n. sp. (Scuticociliatida: Orchitophryidae), a marine facultative parasitic ciliate of the Dun-

Editorial responsibility: Tim Flegel,

Bangkok, Thailand geness crab, Cancer magister. Trans Am Microsc Soc 113: $343-364$

Morado JF, Small EB (1995) Ciliate parasites and related diseases of Crustacea: a review. Rev Fish Sci 3:275-354

O'Halloran MJ, O'Dor RK (1988) Molt cycle of male snow crabs, Chionoecetes opilio, from observations of external features, setal changes, and feeding behavior. J Crustac Biol 8:164-176

Paul AJ (1984) Mating frequency and viability of stored sperm in the tanner crab Chionoecetes bairdi (Decapoda, Majidae). J Crustac Biol 4:375-381

Paul AJ, Adams AE, Paul JM, Feder HM, Donaldson WE (1983) Some aspects of reproductive biology of the crab Chionoecetes bairdi. Univ. Alaska, Alaska Sea Grant Rep. 83-1:1-32

Poisson R (1930) Observations sur Anophrys sarcophaga Cohn (= A. maggii Cattaneo) infusiore holotriche marin et sur son parasitieme possible chez certains crustaces. Bull Biol Fr Belg 64:288-331

Sawyer TK (1969) Preliminary study on the epizootiology and host-parasite relationship of Paramoeba sp. in the blue crab, Callinectes sapidus. Proc Natl Shellfish Assoc 59: $60-64$

Sherburne SW, Bean LL (1991) Mortalities of impounded and feral Maine lobsters, Homarus americanus H. MilneEdwards, 1837, caused by the protozoan ciliate Mugardia (formerly Anophrys = Paranophrys), with initial prevalence data from ten locations along the Maine Coast and one offshore area. J Shellfish Res 10:315-326

Sindermann CJ (1990) Principal diseases of fish and shellfish, Vol. 2. Diseases of marine shellfish, 2nd edn. Academic Press, San Diego

Sparks AK (1985) Synopsis of invertebrate pathology. Elsevier Science Publisher BV, Amsterdam

Sparks AK, Hibbits J, Fegley JC (1982) Observations on the histopathology of a systemic ciliate (Paranophrys sp.?) disease in the Dungeness crab, Cancer magister. J Invertebr Pathol 39:219-228

Sprague V, Beckett RL (1966) A disease of blue crabs (Callinectes sapidus) in Maryland and Virginia. J Invertebr Pathol 8:287-289

Sprague V, Beckett RL (1969) A new species of Paramoeba (Amoebida, Paramoebidae) parasitic in the crab Callinectes sapidus. J Invertebr Pathol 14:167-174

Tuffrau M (1967) Perfectionnements et pratique de la technique d'impregnation au protargol des infusoires cilies. Protistologica 3:91-98

Submitted: November 14, 1998; Accepted: July 14, 1999

Proofs received from author(s): October 28, 1999 